\title{
Climate \& Sustainability Implications of Land Use Alterations in an Urbanizing Region: Raleigh-Durham, North Carolina
}

\author{
E. M. B. Doran, J. S. Golden \\ Division of Earth and Ocean Sciences, Nicholas School of the Environment, Duke University, Durham, USA \\ Email:emb.doran@duke.edu, jay.golden@duke.edu
}

Received 18 April 2016; accepted 26 June 2016; published 29 June 2016

Copyright $(\underset{2016}{ } 2 \mathrm{by}$ authors and Scientific Research Publishing Inc.

This work is licensed under the Creative Commons Attribution International License (CC BY).

http://creativecommons.org/licenses/by/4.0/

(c) (i) Open Access

\begin{abstract}
Urban climate is the most immediate manifestation of the warming global climate for the majority of people on earth. Nearly half of those people live in small to medium sized cities, an understudied scale in urban climate research. Widespread characterization would be useful to decision makers in planning and design for land use decisions. Using a multi-method approach, the mesoscale UHI in the study region is characterized and the secular trend over the last sixty years evaluated. Under isolated ideal conditions the findings indicate a $\mathrm{UHI}$ of $5.3^{\circ} \mathrm{C} \pm 0.97^{\circ} \mathrm{C}$ to be present in the study area, the magnitude of which is growing over time.
\end{abstract}

\section{Keywords}

Land Use, Urban Heat Island, Mesoscale, Urban Climate, Piedmont, North Carolina

\section{Introduction}

Global climate is an area of active research and ongoing attention by the international scientific community [1] [2]. With more than half the world's current population living in cities as of 2007 [3], a trend that is projected to continue to increase, urban climate is the most immediate manifestation of the changing Earth for the majority of people on the planet [4]. In areas where urbanization and significant land use change is occurring, evidence suggests the strength of urban climate warming signals is growing faster than the global mean climate [5] [6] which can have significant environmental implications such as increased water and energy consumption [7] and on air quality [8].

Since the modern era of scientific observations and Luke Howard's early 1800s work in London [9], the Urban Heat Island (UHI) has been observed in cities of various sizes around the world [10] [11]. The UHI is de- 
fined as the warmer nature of the urban environment compared to the surrounding rural environs, including surfaces and canopy and boundary layer air masses [9] [10] — a manifestation of land use and land cover decisions and actions.

At the same time anthropogenic emissions are driving the rise in global mean temperatures, the overall growth and rapid urbanization of the planet's population-from 30 percent urban in 1950 to 54 percent urban in 2014 while nearly tripling the total population - are driving a transition from native vegetation and land cover types to engineered infrastructure and land typologies that in some cases have dramatically different thermodynamic properties [4] [12]-[14].

In the United States, UHI studies have largely focused on characteristically dense urban cities where UHI signals are the strongest. In the arid southwest, for example, researchers have used the city of Phoenix, AZ to investigate various aspects of the physical UHI phenomenon including the correlation of magnitude with population, as well as impacts and mitigation opportunities [15]. UHI research has also centered around the humid sub-tropical cities of Houston, TX [16] [17] and Atlanta, GA [18]. The city of Houston, TX, as the fourth largest city in the country by both population and land area [19], has drawn interest from researchers demonstrating specific remote sensing [17] and regional scale climate modeling [16] methods, while the Atlanta, GA UHI has been found to exhibit strong perturbation effects on the local hydrologic cycle with increased storm events concentrated in and affecting specific parts of the city [18]. Similarly, in the coastal city of New York, NY the urban heat island has some potential to stimulate the formation of a sea breeze front due to differential heating between the urban environment and adjacent ocean [20]. Studies linking the impacts of urban heat islands to socioeconomic conditions have also focused on larger cities including Philadelphia, PA, finding that social and economic indicators can be used to identify geographic areas with higher risk to morbidity and mortality [21]. The studies referenced here are not intended to be exhaustive of all UHI research but be representative of the majority of the UHI research.

Relatively little research has focused on urban areas (smaller than 500,000 residents) and small cities (500,000 to 1 million residents) and in regional configurations of multiple small connected cities, despite the fact that cities with populations under 500,000 were home to almost half the world's urban population as of 2014 [3]. While fully two thirds of Europeans live in these small urban areas, the largest growth is occurring in Africa and Asia where more than half of the population lives in small or medium urban areas of less than one million residents [3].

Although understudied in the most common context, there is increasingly clear evidence of the consequences of land use alterations. A recent review summarizing 50 years of UHI research in 225 cities, suggests the UHI results in increased consumption of energy, higher levels of urban environmental pollution, lower thermal comfort for residents, and increased mortality [22]. Additional reviews of recent literature publications concur; UHI impacts include adverse effects on human health including morbidity and mortality [23] [24]; environmental degradation of adjacent natural ecosystems including water bodies, and wildlife; and economic impacts arising from compromised human comfort profiles [6] [11].

To begin to address the nexus of land use decisions and environmental impacts (climatic) in small and medium sized, regionally connected cities, this study focuses on a rapidly growing region of the United States where the impact of the findings has the potential to support policy-makers around the globe.

\section{The Piedmont Region}

The study region is shown in Figure 1 and comprised of three counties, Wake, Durham and Orange which cover 4000 square kilometers in the central Piedmont region of North Carolina centered around 35.8 latitude, -78.8 longitude. The cities of Raleigh, Durham, and Chapel Hill respectively comprise roughly 17 percent of the land area in the combined counties. Topographically, the study area is characterized by rolling hills with an average elevation of $120 \mathrm{~m}$ above sea level. The Appalachian Mountains range runs northeast-southwest $150 \mathrm{~km}$ to the northwest of the study region while the Atlantic Ocean is $200 \mathrm{~km}$ southeast.

The area is anchored by three major universities: Duke University in Durham, University of North Carolina in Chapel Hill, and North Carolina State University in Raleigh. The research triangle is also home to the Research Triangle Park which is the largest research park in the United States with more than 200 companies including large technology and pharmaceutical companies, and major government research laboratories that employ more than 50,000 people, approximately $80 \%$ of whom work for multi-national companies [25]. 


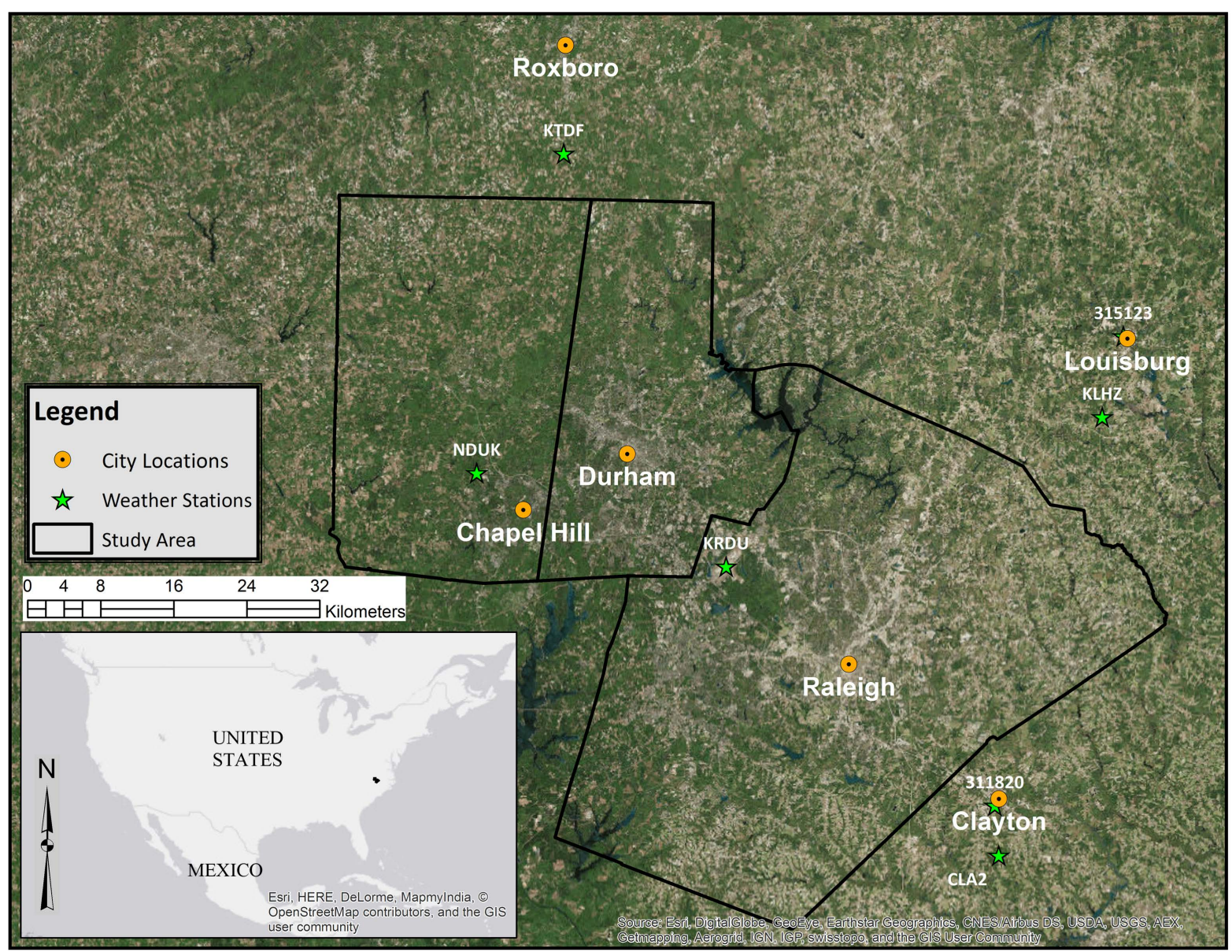

Figure 1. Study area and weather station locations.

The study region also serves as the northern terminus of the Piedmont megaregion which extends down the I85 corridor through Charlotte, North Carolina to Atlanta, Georgia [26]. Defining the geographic scale of a megaregion requires consideration of the integration of economic factors, natural resources, ecosystems, transportation and population that extends beyond the standard political boundaries of metropolitan areas [26]. The Piedmont megaregion is characterized by a combination of fast growing smaller regions and older more established regions. For example, the Piedmont megaregion is home to three of the top 15 fastest growing cities in the United States in 2014 including Raleigh, North Carolina which ranked second; Charlotte, North Carolina which ranked eighth; and, Atlanta, Georgia, a city much older than the other two, which ranked twelfth [27]. This is in contrast to the Northeast megaregion, for example, which extends down the I-95 corridor from Boston, Massachusetts to Washington, DC and is comprised of older, slower growth regions, that tend to have longer history, be well established, and are well connected.

One of four megaregions identified in the United States Census South region [26], the study area is further part of the fastest growing Census regions in the country [28]. Comprised of 16 states and the District of Columbia, the South region was home to roughly 37\% of the total United States population in 2005.

\subsection{Projected Future Growth}

The current growth rates evident in the study area are projected to continue with significant land use and land cover changes and their associated implications for the region as a whole and for the study area specifically. At the regional level, the United States Census South is projected to continue to grow with intensification in regions already identified as megaregions including the Piedmont. Based on analysis done by Bierwagen, Thomas [28] to adapt the IPCC SRES storylines to the United States [29], the South region could grow to encompass between 
$38 \%$ and $39 \%$ of the population by 2030 while growing between $22 \%$ and $30 \%$ overall.

In the Raleigh-Durham-Chapel Hill study area, projections of population growth and distribution compiled as part of the 2040 Long Range Transportation Planning report indicate that while employment is likely to see growth in the exiting transportation and urban core areas, new homes are likely to be split between the urban downtown cores, and the regional fringes, contributing to continued sprawl [30]. Growth in Durham County is projected to be stronger, 1.7 percent per year, than growth within the city limits, 1.5 percent, while the City of Raleigh and Wake County are both expected to exceed 100\% growth relative to 2000 Census figures, with annual growth rates around 2.2 percent [31]. These projections are comparable to and even outstrip projected rates of urbanization for African and Asian countries [3].

\subsection{Regional Climate Characteristics}

The Raleigh-Durham-Chapel Hill region of North Carolina, experiences a humid subtropical climate [32]. Based on data collected at the ASOS weather station at the Raleigh-Durham International Airport (KRDU) available from the State Climate Office of North Carolina and shown in Figure 2, average maximum temperatures are around $30^{\circ} \mathrm{C}$ in the summer months (June-July-August) and $10^{\circ} \mathrm{C}$ in the winter (December-January-February), and average minimum temperatures are around $20^{\circ} \mathrm{C}$ in the summer months and $0^{\circ} \mathrm{C}$ in the winter. Further, precipitation trends are relatively consistent over the last six decades with an average of $2-3 \mathrm{~mm}$ of rain per day except during the late summer, early fall (July-August-September) when the average precipitation is not only higher (up to 5 - $6 \mathrm{~mm}$ per day), but also more variable.

Two regional climatological analyses have been conducted in the study region, both focused on extreme heating. The first, an analysis of synoptic scale summer heat events in the Piedmont between 1951 and 1993 [33] ends in the middle of a period of rapid population growth that extends into the 1990s. The second study focuses
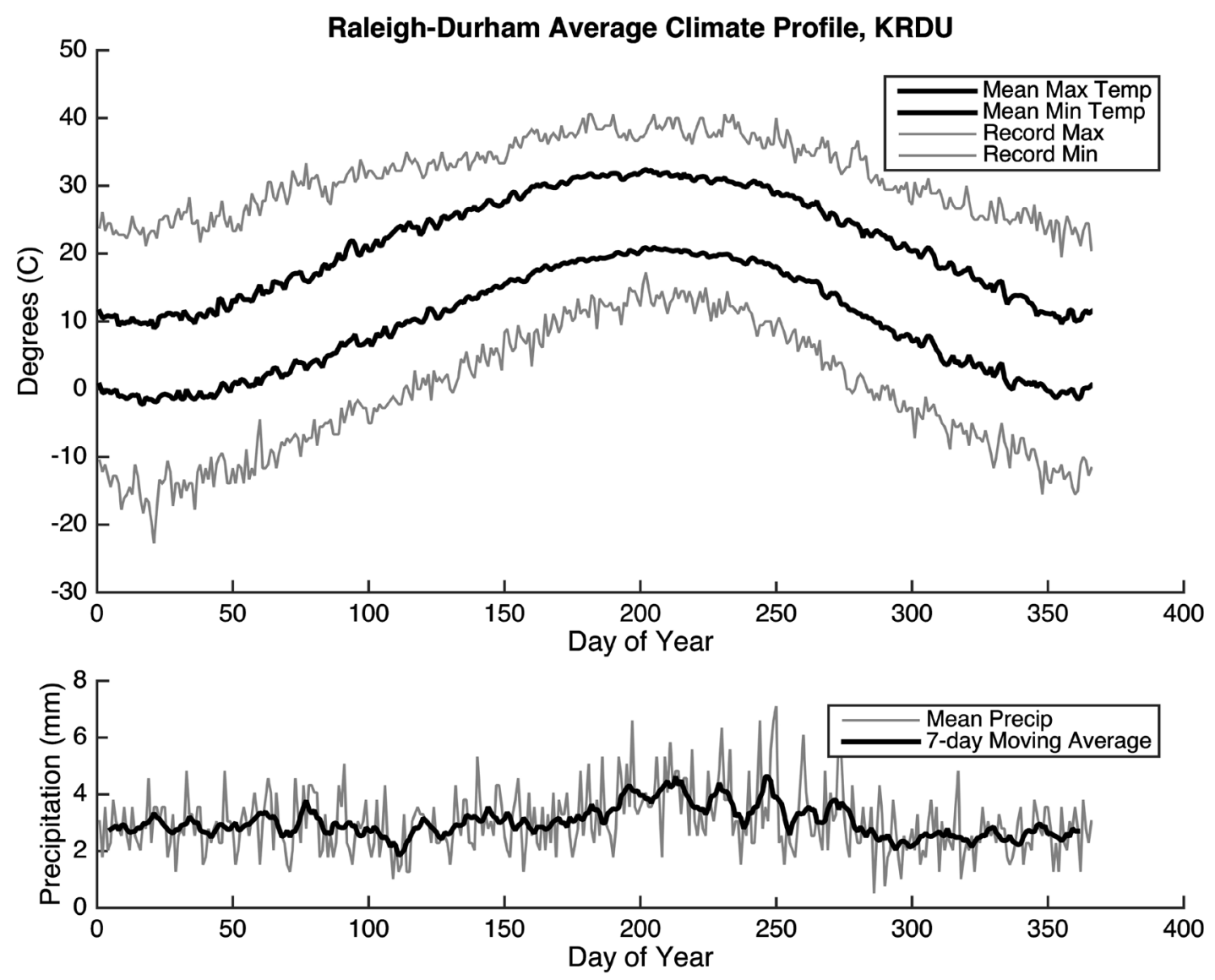

Figure 2. KRDU mean climate characteristics summary for study region including temperature (top) and precipitation (bottom). 
on the North Carolina heat wave in 2007 which was an exceptional period in which hundreds of daily maximum and daily high minimum temperature records as well as several all-time temperature records in the state were either tied or broken [34]. The two studies indicate that summer heating conditions in particular are influenced roughly half the time by prevailing southwesterly winds around the Bermuda High or downs loping westerly winds off the Blue Ridge mountains. Both high humidity and low humidity type heating events occur in the study region subject to the same synoptic scale conditions with humidity controlled by regional advection or precipitation in the 30-day window antecedent to a heat event [33]. The mixing depth in the boundary layer was also found to be important and to be controlled by the dry soil conditions leading to midafternoon decreases in the heat index despite continued increases in overall temperature [34].

\subsection{Previous UHI Research \& Research Questions}

Limited efforts have been made to characterize the UHI in the study area, however the cities of Raleigh and Durham have appeared in regional, multi-city analyses. Chen and Konrad II [33], for instance, report an average temperature difference between the weather station at the Raleigh-Durham Regional Airport (KRDU) and unspecified cooperative observer sites of $0.8^{\circ} \mathrm{C}$ during the timespan of their study (1951-1993) but do not report a secular trend. In another case, Durham was included in an evaluation of the UHI for18 cities in the states of North and South Carolina from 1971-2000 finding evidence that UHIs were present, and that their strength could be correlated to population [35]. Finally, the city of Raleigh, NC was included in a modeled study using data from the NASA MODIS satellite of 65 North American cities that found daytime UHI strength is strongly correlated with mean annual precipitation while nighttime UHI strength is correlated with population [36].

Work specific to the study area does include limited attention to drivers and impacts of the UHI. For instance, urban tree cover has long been considered a mitigation approach for reducing the UHI strength despite a lack of clear guidance for design and implementation [37]. Of two studies focused on tree cover in the City of Raleigh, one suggests the correlation of morphological characteristics (e.g. lot size, age of construction) with the distribution of urban tree coverage [38], while the other indicates a negative correlation of urban tree cover with percent Black residents [39] with implications for social justice. An additional study investigating UHI impacts in the study area included findings that suggest urban warming is a key driver of pest abundance and outbreaks on urban trees [40]. Finally, an analysis of emergency room visits across North Carolina during the heat waves of 2007 and 2008 found that temperature effects were greatest for middle aged men, and more commonly residents of rural counties [41]. This finding may be logical given the agricultural nature of the state's economy, the fact that daytime UHI is often negative, with rural temperatures exceeding those in urban areas, however additional work would be needed to assess time lags, the correlation with maximum instead of mean daily temperatures, and the impact of acute heat-wave events.

Given the attention to morphological drivers and impacts and the lack of careful regional characterization, we therefore seek to address the following questions: How strong is the UHI in the study region? Is it growing over time, and is this growth explained by trends in population or land use change? Finally, given the humid subtropical climate of the study region, what is the relative importance of controlling for climatological conditions in these findings?

\section{Data Sources and Methodology}

To characterize the current distribution of the regional UHI, we utilize 1) remote sensing techniques. To determine the magnitude of the regional UHI over time, two methods were used: 2) monthly average minimum and maximum UHI, and 3) diurnal hourly UHI including passive climatological control.

\subsection{Remote Sensing Method}

To begin to characterize the spatial distribution of the UHI across the study region, thermal infrared (TIR) data collected by the Landsat-8 OLI-TIRS satellite was used. Band 10 of the TIR aboard Landsat 8 collects light in the wavelength $10.60-11.19 \mu \mathrm{m}$. Because interest is exclusively in the relative strength of the regional surface-heat profile from a single image, the image data was corrected to At Satellite Brightness Temperature which does not include an atmospheric correction interference [42]. Conversion formulas are provided by the US Geological Survey and the correction factors are provided in the metadata compiled with the scene data [43]. 
The TIR Band 10 data is first converted to top of atmosphere (TOA) spectral radiance according to Equation (1) [43].

$$
L_{\lambda}=M_{L} Q_{c a l}+A_{L}
$$

where the TOA spectral radiance, $L_{\lambda}$, has units of Watts $\cdot \mathrm{m}^{-2} \cdot \mathrm{s} \cdot \mathrm{rad}^{-1} \cdot \mu \mathrm{m}^{-1}$, and where the band-specific multiplicative rescaling factor, $M_{L}$, equals $3.3420 \mathrm{E}-04$; the addative rescaling factor $A_{L}$, equals 0.1000 ; and where, $Q_{c a l}$, is the quantized standard product pixel values.

The TOA spectral radiance is then converted to at satellite brightness temperature using Equation (2) [43].

$$
T=\frac{K_{2}}{\ln \left(\frac{K_{1}}{L_{\lambda}}+1\right)}-273.15
$$

where temperature, $T$, is corrected to degrees Celsius, and where the thermal correction constants are as follows: $K_{1}=774.0853$ and $K_{2}=1321.0789$.

The transect data obtained from the processed image was smoothed using a 15 point moving average. The smoothed data was used to calculate temperature differences between weather station locations.

In addition, the 2011 National Land Cover Database for the study area was aggregated into two land cover classifications: urban and rural, with water appearing separately. Urban areas included all developed land classifications (21 - 24) including developed open space as well as low, medium and high density development [44] [45]. The mean temperature was then calculated for each of the two land cover types (urban and rural) using the spatial analyst tool in the ArcGIS environment.

\subsection{Mean Monthly Method}

Data used in this study was collected from five hourly weather stations and two daily weather stations in and around the study region (see Figure 1). The stations used in the analysis including their characteristics (e.g. station type, elevation and date of first record) are summarized in Table 1 while instrument data at each station network is summarized in Table 2. Criteria for station selection included 1) length of climate record, 2) availability of hourly temperature data, and 3) urban or rural location. In the study region, the weather stations with the longest temporal record are those that only record daily observations. The daily stations are part of the National Weather Service Cooperative Observer (COOP stations) program and record observations of minimum and

\begin{tabular}{|c|c|c|c|c|c|c|c|c|c|}
\hline $\begin{array}{l}\text { Station } \\
\text { ID }^{\mathbf{a}}\end{array}$ & Station name & Near city & $\begin{array}{l}\text { First } \\
\text { record }\end{array}$ & Network & $\begin{array}{l}\text { Elevation } \\
\text { (m ASL) }\end{array}$ & Lat & Long & $\begin{array}{c}\text { LCZ } \\
\text { subclass }^{\text {b }}\end{array}$ & $\begin{array}{c}\text { Distance } \\
\text { from } \\
\text { KRDU } \\
\text { (km) }\end{array}$ \\
\hline \multicolumn{10}{|c|}{ Hourly stations } \\
\hline KRDU & $\begin{array}{c}\text { Raleigh-Durham } \\
\text { Airport }\end{array}$ & $\begin{array}{c}\text { Raleigh/ } \\
\text { Durham, NC }\end{array}$ & $7 / 1 / 48$ & ASOS-standard & 133 & 35.87764 & -78.78747 & $6 \mathrm{D}$ & - \\
\hline CLA2 & $\begin{array}{l}\text { DAQ Clayton } \\
\text { Profiler }\end{array}$ & Clayton, NC & $8 / 2 / 03$ & ECONET-tower & 76 & 35.59158 & -78.45889 & CA & 43 \\
\hline KLHZ & $\begin{array}{c}\text { Franklin County } \\
\text { Airport }\end{array}$ & Louisburg, NC & $1 / 25 / 03$ & AWOS -III & 112 & 36.02335 & -78.33027 & DA & 44 \\
\hline KTDF & $\begin{array}{c}\text { Person County } \\
\text { Airport }\end{array}$ & Roxboro, NC & $12 / 14 / 00$ & AWOS -III & 186 & 36.28489 & -78.98423 & $\mathrm{DB}$ & 49 \\
\hline NDUK & Duke Forest & Carrboro, NC & $3 / 30 / 00$ & RAWS & 172 & 35.97 & -79.09 & A & 29 \\
\hline \multicolumn{10}{|c|}{ Daily stations } \\
\hline 311820 & Clayton Wtp & Clayton, NC & $11 / 1 / 55$ & COOP-TP & 91 & 35.64083 & -78.46333 & $9 \mathrm{D}$ & 39 \\
\hline 315123 & Louisburg & Louisburg, NC & $\begin{array}{c}\text { January } 1, \\
1893\end{array}$ & COOP-TP & 79 & 36.10278 & -78.30389 & $9 \mathrm{D}$ & 50 \\
\hline
\end{tabular}

Table 1. Weather station general information summary.

Notes: ${ }^{a}$ Station Locator: http://climate.ncsu.edu/CRONOS/; ${ }^{b} L C Z$ Classification based on Setwart \& Oke, 2012; 'Lat/Long calculator: http://www.nhc.noaa.gov/gccalc.shtml. 
Table 2. Weather station network temperature and precipitation sensor technical specifications.

\begin{tabular}{|c|c|c|c|c|c|c|}
\hline Networ & & ASOS-standard & ECONET-tower & AWOS-III & RAWS & COOP-TP \\
\hline \multirow{4}{*}{ Temperature } & Sensor & $\mathrm{RTD}^{\mathrm{b}}$ & $\begin{array}{c}\text { Ceramic } \\
\text { capacitance }\end{array}$ & $\mathrm{RTD}^{\mathrm{b}}$ & $\begin{array}{l}\text { Platinum } \\
\text { resistance }\end{array}$ & $\mathrm{MMTS}^{\mathrm{d}}$ \\
\hline & Range & $-62^{\circ} \mathrm{C}$ to $54^{\circ} \mathrm{C}$ & $-52^{\circ} \mathrm{C}$ to $60^{\circ} \mathrm{C}$ & $-128^{\circ} \mathrm{C}$ to $54^{\circ} \mathrm{C}$ & $-50^{\circ} \mathrm{C}$ to $+50^{\circ} \mathrm{C}$ & $-48^{\circ} \mathrm{C}$ to $52^{\circ} \mathrm{C}$ \\
\hline & Accuracy & $\begin{array}{c}\mathrm{RMSE}^{\mathrm{c}}: \\
1.1^{\circ} \mathrm{F}-7.9^{\circ} \mathrm{F}\end{array}$ & $\begin{array}{l} \pm 0.2^{\circ} \mathrm{C} \text { at }-40^{\circ} \mathrm{C} \text {, } \\
\pm 0.3^{\circ} \mathrm{C} \text { at } 20^{\circ} \mathrm{C} \\
\pm 0.4^{\circ} \mathrm{C} \text { at } 40^{\circ} \mathrm{C}\end{array}$ & $\mathrm{RMSE}^{\mathrm{c}}:$ of $\pm 1.8^{\circ} \mathrm{F}$ & $\pm 0.6^{\circ} \mathrm{C}$ & $\pm 0.3^{\circ} \mathrm{C}$ \\
\hline & $\mathbf{D R R}^{\mathbf{a}}$ & $60 \mathrm{~min}$ & $30 \mathrm{~min}$ & $60 \mathrm{~min}$ & $60 \mathrm{~min}$ & 24 hour \\
\hline \multirow{4}{*}{ Precipitation } & Sensor & $\begin{array}{l}\text { Heated tipping } \\
\text { bucket }\end{array}$ & $\begin{array}{l}\text { Tipping bucket } \\
\text { rain gage }\end{array}$ & $\begin{array}{l}\text { Heated tipping } \\
\text { bucket }\end{array}$ & Tipping bucket & $\begin{array}{l}\text { Std Rain Gage or } \\
\text { Fischer \& Porter }\end{array}$ \\
\hline & Range & $0-10 \mathrm{in} / \mathrm{hr}$ & $\begin{array}{c}\text { Infinite in } \\
\text { increments of tips }\end{array}$ & $\begin{array}{c}\text { Infinite in } \\
\text { increments of tips }\end{array}$ & 0 - 99.99 in & $\begin{array}{l}0 \text { - } 8 \text { in(SRG), } \\
0 \text { - } 20 \text { in (F\&P) }\end{array}$ \\
\hline & Accuracy & $\begin{array}{l} \pm 0.02 " \text { or } 4 \% \\
\text { hourly total }\end{array}$ & $\pm 0.5 \mathrm{kt}$ & $\begin{array}{l}\text { Within } 1 \% \text { if }<1 \\
\text { in/hr, }-3 \% \text { if } \\
1-2 \mathrm{in} / \mathrm{hr} \\
-5 \% \text { if } 2-3 \mathrm{in} / \mathrm{hr}\end{array}$ & $\begin{array}{l}\text { Within } \pm 3 \% \text { of } \\
\text { total }\end{array}$ & $\begin{array}{c}\text { Within } \pm 1 \% \text { to } \\
5 \%\end{array}$ \\
\hline & $\mathbf{D R R}^{\mathrm{a}}$ & $60 \mathrm{~min}$ & $30 \mathrm{~min}$ & $60 \mathrm{~min}$ & $60 \mathrm{~min}$ & 24 hour \\
\hline \multirow{4}{*}{$\begin{array}{c}\text { Wind } \\
\text { speed/gust }\end{array}$} & Sensor & Cup anemometer & Helicoid propeller & Cup anemometer & $\begin{array}{l}\text { Cup anemometer } \\
\text { or transducers }\end{array}$ & Cup anemometer \\
\hline & Range & 0 to $125 \mathrm{kt}$ & $\begin{array}{c}\text { Sustained } \\
0-116 \mathrm{kt} \text {, } \\
\text { gusts } 0-191 \mathrm{kt}\end{array}$ & 0 to $125 \mathrm{kt}$ & $87 \mathrm{kt}$ & $0-135 \mathrm{kt}$ \\
\hline & Accuracy & $\begin{array}{l} \pm 2 \text { kt or within } \\
5 \% \text { whicever is } \\
\text { greater }\end{array}$ & $\pm 0.5 \mathrm{kt}$ & $\begin{array}{l} \pm 2 \text { kt or within } 5 \% \\
\text { whicever is greater }\end{array}$ & $\pm 5 \%$ & $\pm 1.1 \%$ \\
\hline & $\mathbf{D R R}^{\mathrm{a}}$ & $60 \mathrm{~min}$ & $30 \mathrm{~min}$ & $60 \mathrm{~min}$ & $60 \mathrm{~min}$ & $24 \mathrm{hr}$ \\
\hline \multirow{4}{*}{$\begin{array}{l}\text { Wind } \\
\text { direction }\end{array}$} & Sensor & Vane & Potentiometer vane & Vane & Vane & - \\
\hline & Range & 0 to 359 degrees & $\begin{array}{c}360 \text { degree } \\
\text { mechanical, } \\
0 \text { - } 355 \text { degree } \\
\text { electrical }\end{array}$ & 0 to 359 degrees & 0 - 360 degrees & - \\
\hline & Accuracy & $\begin{array}{l} \pm 5 \text { deg when } \\
\text { speed is }<5 \mathrm{kt}\end{array}$ & \pm 3 degrees & $\begin{array}{l} \pm 5 \text { deg when speed } \\
\text { is }<5 \mathrm{kt}\end{array}$ & $\pm 5 \%$ & - \\
\hline & $\mathbf{D R R}^{\mathrm{a}}$ & $60 \mathrm{~min}$ & $30 \mathrm{~min}$ & $60 \mathrm{~min}$ & $60 \mathrm{~min}$ & - \\
\hline
\end{tabular}

Notes: ${ }^{\mathrm{a}}$ Data reporting rate; ${ }^{\mathrm{b}}$ Resistive temperature device; ${ }^{\mathrm{c}}$ Root mean square error; ${ }^{\mathrm{d}} \mathrm{max}$-min temperature system.

maximum daily air temperature (see Table 1 and Table 2). The historically rural and agricultural nature of the study area means these stations are typically located in rural areas, limiting the available choices for a representative urban station with a long temporal record for use in this investigation. Consistent with previous mesoscale UHI studies [46], the hourly weather station at the regional airport-KRDU—is therefore designated as the urban station. While the COOP station in Louisburg, NC has a record that extends back to 1893, the choice of KRDU as the urban station limits the characterization made here to the full extent of that station's temporal record, 1948-2015.

The hottest and driest months in the study area were isolated based on mean climatological conditions at the urban station which is also centrally located in the study area. At the KRDU ASOS weather station, the mean temperature in June is $24^{\circ} \mathrm{C}$ while on average the month of July is slightly warmer at $25.9^{\circ} \mathrm{C}$. June on the other hand is the dryer month, with an average mean precipitation of $3 \mathrm{~mm}$ compared to the July average of $4 \mathrm{~mm}$.

Having selected the seasonal window to include the calendar months of June and July, the monthly mean high and low temperature was calculated at each station location included in the analysis for the years 1944-2014 in each month as follows. 


$$
\begin{aligned}
T_{M \text { max }} & =\frac{\sum_{d=1}^{n} D T_{\text {max }}(d)}{n} \\
T_{M \text { min }} & =\frac{\sum_{d=1}^{n} D T_{\text {min }}(d)}{n}
\end{aligned}
$$

where $T$ is the mean monthly temperature, $n$ is the total number of days in the month, $M$, of interest, and where the daily minimum and maximum temperature, $D T$, is a function of the day of the month, $d$.

The strength of the urban heat island was then calculated using Equation (5):

$$
\Delta T_{M}=T_{M u}-T_{M r}
$$

A linear least squares regression analysis was then used to test the strength of the UHI magnitude for secular trends. The daily COOP stations record precipitation as well as temperature. To assess the impact of precipitation on the mean monthly method for calculating the UHI, the total daily precipitation over the course of the months of interest was also calculated for inclusion in the regression analysis.

\subsection{Diurnal Hourly Method}

While UHI investigations in climatologically favorable locations have made findings of significant change over time using the temporally averaged methods described above (e.g. Golden [46]), the importance of the passive control of climatologic conditions has also been previously demonstrated [10] [47]. Passive control includes isolating dry, clear, and calm meteorological conditions within the historical record, and then measuring the UHI diurnally on an hourly basis. The importance of passive control on the resulting characterization of the regional UHI is investigated here by inclusion of four additional hourly stations. These stations have records that enable detailed investigation of the recent past, specifically the time period between 2000 and 2015. The strongest UHI has previously been found to occur at night when advection, mixing and heating processes are at a minimum [10] [22] [47], so the diurnal evaluation allows for the additional test of this condition in the study area.

The hourly station observations used in this study include 2-meter air temperature, precipitation, wind speed and direction. The stations are part of observing networks maintained by the National Weather Service (ASOS stations), North Carolina State Climate Office (ECONet stations), North Carolina Department of Transportation, Federal Aviation Administration (AWOS stations), and the National Wildfire Coordination Group (RAWS stations). Data for the seven stations used in the regional climate analysis were obtained by special request from the State Climate Office of North Carolina.

There are several kilometers between stations (see Table 1), so the focus here is on characterization of the mesoscale aspects of the UHI.

Passive climatological control was accomplished by first calculating the moving three-day average of maximum daily temperature for the KRDU ASOS Airport station and ranking the result for each day over the 16-year period from 2000 to 2015. The hottest 6 percent of these dates was extracted and the precipitation was calculated for each date. Dates with evidence of precipitation were removed from the sample leaving roughly two percent of the total sample, or 118 dates for further analysis.

Hourly data for each hourly station included in the analysis was then retrieved for each three-day period represented by the 118 dates from the master database of data provided by the North Carolina State Climatology Office. Raw data was first processed to assign observations to the top of the nearest hour. Quality control was then performed on the extracted data including the removal of duplicate hourly data points that 1) contained a null reading, 2) had a time stamp inconsistent (by minute) with other observations, or 3) contained a reading that was discontinuous with adjacent readings. The quality control process resulted in a database that contained a consistent number of readings for all dates and had one reading per hour over the 73-hour period.

The diurnal calculation of the temperature difference between the urban and rural sites was then calculated for each hour, $h$, using Equation (6):

$$
\Delta T_{h_{u-r}}=T_{h_{u}}-T_{h_{r}}
$$

The maximum temperature delta for each date series and urban-rural station pair was then extracted, along with the time of that difference for inter-station comparison. The multiple station temperature delta results were then combined into a single data set. To test for temporal dependency, the mean annual UHI was used to conduct a linear least squares regression analysis. 


\subsection{Land Use and Population Data}

Both changes in land use and cover, and population size have been correlated with the regional scale intensity of the observed UHI [4] [48].

Land use data was obtained from the National Land Cover Database products available from the Multi-Resolution Land Characteristics consortium of federal agencies [49]. Since the products for the years 1992, 2001, 2006 and 2011 were not all calculated using the same satellites or land cover classification algorithms, the 15 land cover types are collapsed into two categories: urban and rural for comparison. We further make no effort to interpret the impact of specific areas of land change on the regional UHI characterization. A linear interpolation model was generated based on the input data from the NLCD data products to create a set of data suitable for comparison against the temporal change in the calculated UHI.

Population data for the city and counties encompassed by the study region were obtained from multiple sources including the U.S. Census decadal surveys and local government projections [30] [50]-[52]. A linear interpolation model based on historical census data for the counties that comprise the study area (Durham, Wake and Orange) was used to generate a table of population figures consistent with the time span of the UHI characterizations.

\section{UHI Distribution, Intensity \& Magnitude}

\subsection{UHI Distribution \& Intensity}

The data used in this study was collected by the Landsat 8 satellite on 21 June 2015 at 15:52.44. The distribution and intensity of the regional surface temperature are shown in Figure 3. The temperature distribution in the study area indicates as much as a 28 degree range in the intensity of the surface temperature in the study region.

A transect across the study area that includes the weather stations used in the hourly historical analysis indicate an approximate temperature difference of $8^{\circ} \mathrm{C}$ between the surface temperature at KRDU relative to values recorded near the NDUK and CLA2 weather stations as shown in Figure 4.

The scene used in the analysis was collected in the late afternoon indicating the regional UHI is one that develops over the course of the day. This is in contrast to findings in desert cities where the daytime temperature distribution created hotter environments in the rural areas [15].

The above two methods of characterizing the variation in the magnitude of the potential UHI are fairly fine grained. A more average approach was also considered. The mean temperature of the urban and rural areas of the study region based on NLCD land cover classes were also calculated. The UHI signal was calculated to be $2.1^{\circ} \mathrm{C} \pm 1.3^{\circ} \mathrm{C}$, with water bodies an additional $2.1^{\circ} \mathrm{C}$ cooler than the rural areas. The standard deviation on the mean temperature calculations by land cover type could be caused by the fact that the land cover classifications used in the analysis were four years out of date relative to the TIR data, however, because the data includes a range of development levels, it is suspected that this may also impact the quality of the calculation. Regardless, the result will be comparable to other mean methods used in this analysis.

\subsection{UHI Magnitude \& Temporal Trends}

\subsubsection{Mean Monthly Method}

Using 68 years of data (1948-2015), the mean monthly UHI is characterized and presented in Figure 5. The data set includes the calculated temperature difference for two months per year (June and July) for two station pairs (KRDU \& Louisburg; and KRDU \& Clayton Wtp). The urban station is located at a busy regional airport (KRDU) that has nearly 400 flights per day and three runways. The rural stations are both part of the cooperative observing network and are located adjacent to small towns approximately $50 \mathrm{~km}$ away to the northeast and southeast respectively. Both stations are located at a somewhat lower elevation $(-41.1 \mathrm{~m}$, and $-53.3 \mathrm{~m}$ respectively). This is noted but not corrected in the following calculations.

The nighttime or minimum temperature differences are expected to be a stronger indicator of the urban heat island effect. The magnitude of the mean annual minimum urban-rural temperature difference is $1.2^{\circ} \mathrm{C} \pm 0.75^{\circ} \mathrm{C}$ $(\mathrm{t}(67)=14.2, \mathrm{p}<0.01)$. A linear least squares regression also suggests a modestly increasing secular trend $\left(\mathrm{R}^{2}=\right.$ $0.086, \mathrm{~F}=6.2, \mathrm{df}=66, \mathrm{p}<0.05$ ) although the total county population of the study area is a slightly better predictor over the time period $\left(\mathrm{R}^{2}=0.093, \mathrm{~F}=6.8, \mathrm{df}=66, \mathrm{p}<0.05\right)$. This is in contrast with previous findings [33]. Total precipitation during the two months investigated was not a significant indicator of the strength of the 


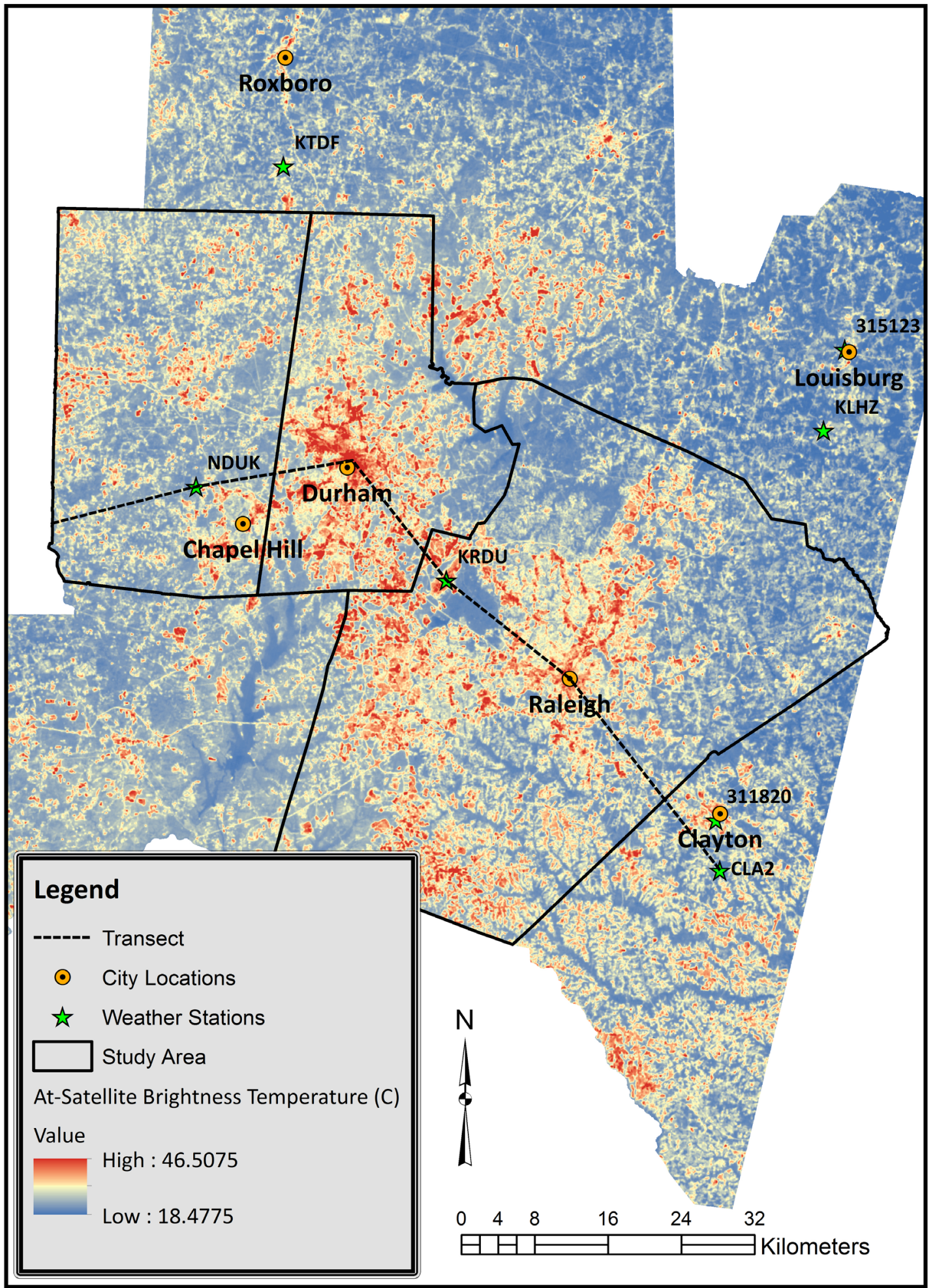

Figure 3. Remotely sensed regional heat intensity and distribution.

UHI for the data set.

The magnitude of the mean annual maximum urban-rural temperature difference was found to be $-0.90^{\circ} \mathrm{C} \pm$ $0.86^{\circ} \mathrm{C}(\mathrm{t}(67)=-8.6, \mathrm{p}<0.01)$. Again, in contrast with previous findings [33], we find here that the mean 


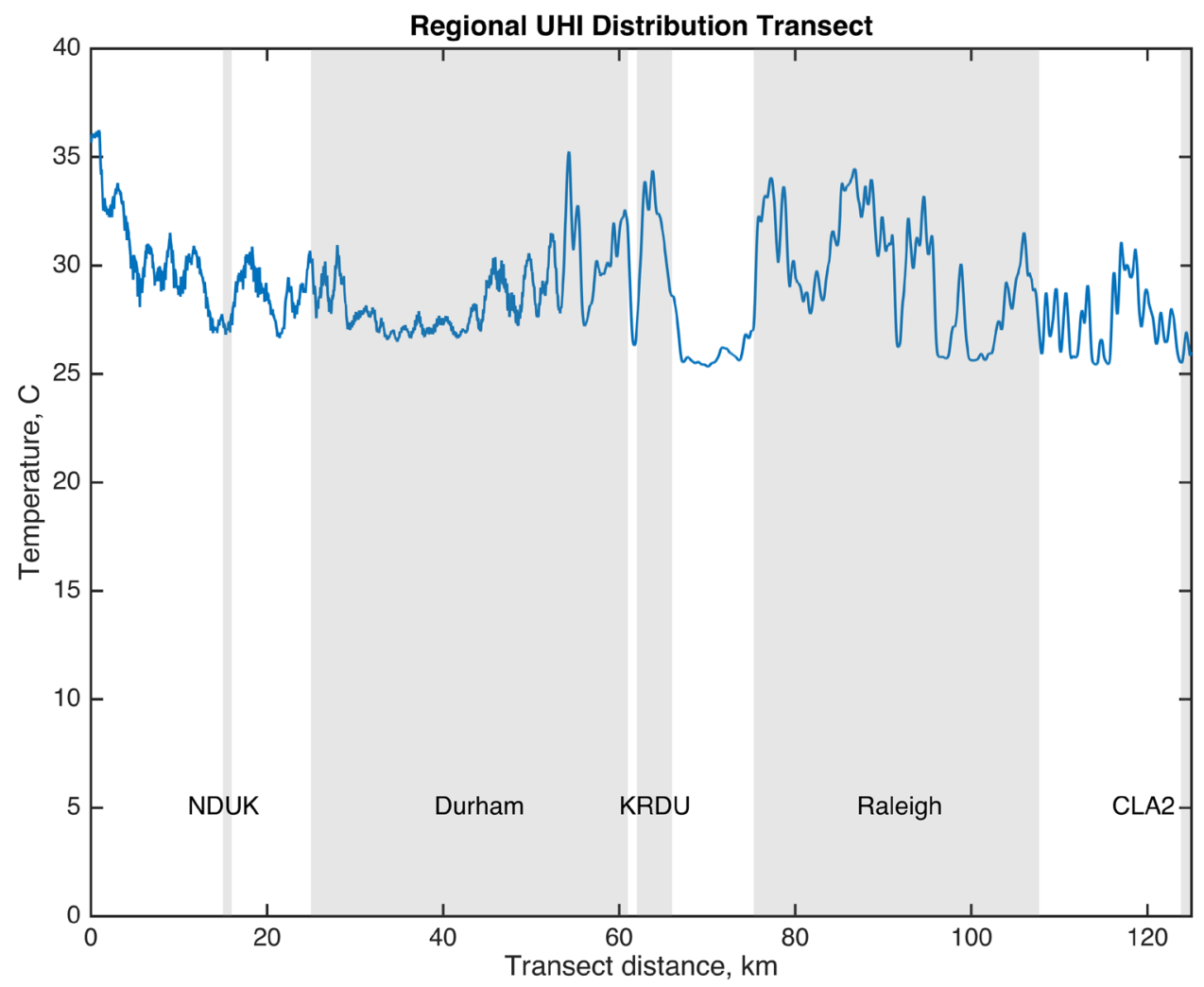

Figure 4. Regional UHI from remotely sensed regional surface heat distribution along transect.

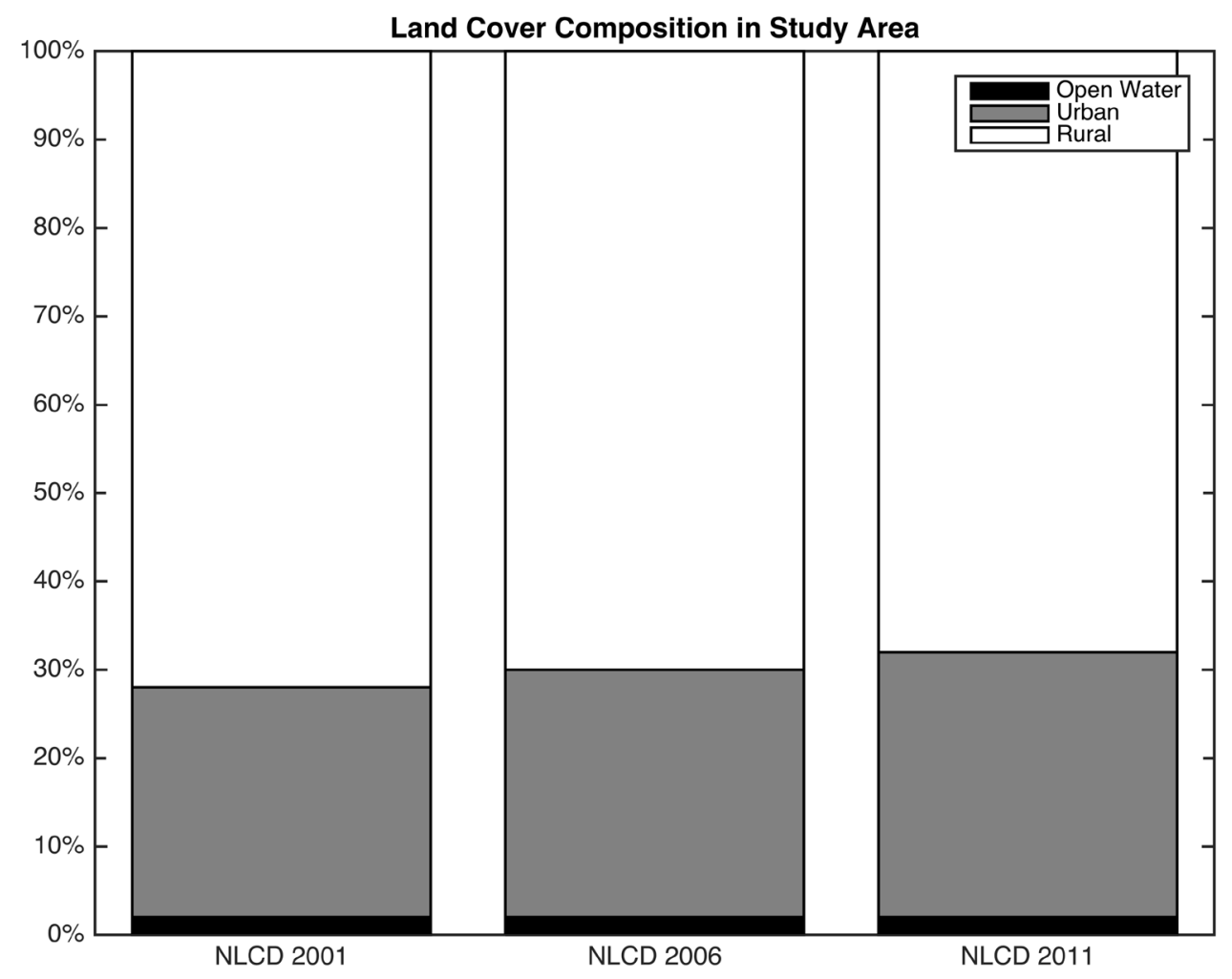

Figure 5. Urban-rural land cover composition in study area. 
maximum UHI is increasing over time and is highly correlated with the increase in population in the study area $\left(\mathrm{R}^{2}=0.506, \mathrm{~F}=67.6, \mathrm{df}=66, \mathrm{p}<0.01\right)$. Combined, this finding indicates that within the study area, urban areas appear to be growing, leading to higher UHI, but also exhibit an urban cool island effect during the day storing energy that is released more slowly than the surrounding rural environs at night. Similar findings have been observed elsewhere [10] [53], however, evaluation of the diurnal dynamics is required to verify this, and is undertaken below.

\subsubsection{Diurnal Hourly Method}

The UHI magnitude characterization using passive climate control and diurnal hourly methods includes 15 years of temperature records (2000-2015) from one urban (KRDU) and four rural stations surrounding the study region (one each northeast, southeast, northwest and west of KRDU). Two of the rural stations are also located at airports, however these are much smaller local airports that experience significantly less regular traffic compared to KRDU and traffic that includes much smaller air planes when it does occur (KLHZ in Louisburg, NC and KTDF in Roxboro, NC). In addition, a station collocated within the Duke University Forest (NDUK), a research forest, and a station located on native vegetation is included in the analysis (CLA2). The elevation profile of the rural stations relative to KRDU ranges from +175 to $-185 \mathrm{ft}$. Elevation is noted but not corrected in the following analysis.

The results of the passive climate control analysis is shown in Figure 6. Unlike the results for the monthly mean UHI method, a clear UHI signal is present between the KRDU and rural stations. The magnitude of the mean UHI signal is $5.3^{\circ} \mathrm{C} \pm 0.97^{\circ} \mathrm{C}(\mathrm{t}(13)=20.5, \mathrm{p}<0.01)$. The result is an indicator of the importance of passive climatological control within the study region. Not only is the magnitude of the UHI significant, a linear least squares regression further indicates a positively increasing trend in the mean annual UHI signal over time $\left(\mathrm{R}^{2}=0.358, \mathrm{~F}=6.7, \mathrm{df}=12, \mathrm{p}<0.05\right)$. As with the mean monthly method, population is again an equally good predictor of the UHI magnitude over the timespan considered, however in this case, both time and population explain more than one third of the variation in the sample $\left(\mathrm{R}^{2}=0.359, \mathrm{~F}=6.7, \mathrm{df}=12, \mathrm{p}<0.05\right)$. Similarly,
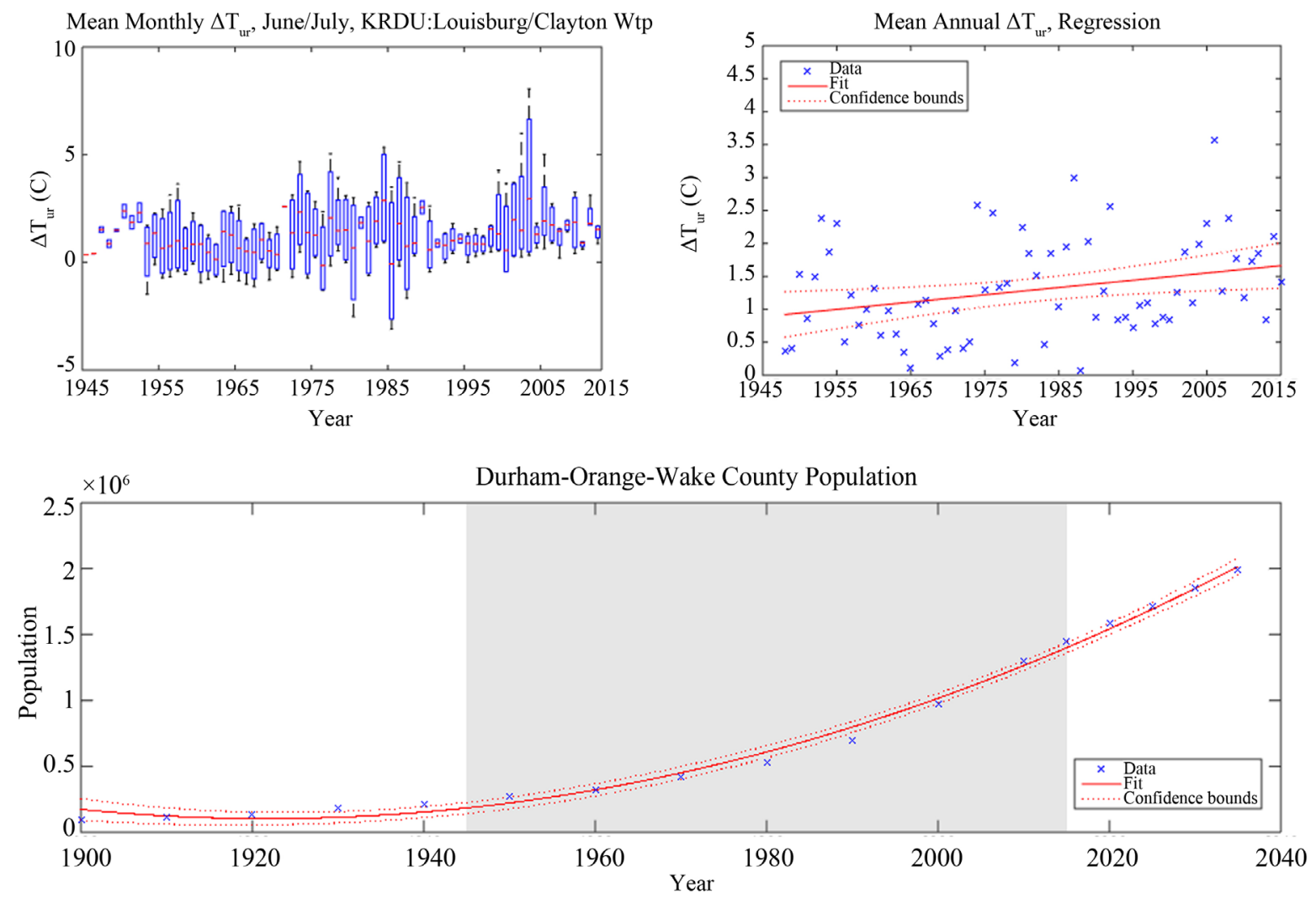

Figure 6. Mean monthly UHI, 1945-2015. 
land cover change was found to explain roughly $30 \%$ of the growth in the regional UHI signal, however only to a 94 percent confidence interval $\left(\mathrm{R}^{2}=0.281, \mathrm{~F}=4.7, \mathrm{df}=12, \mathrm{p}<0.06\right)$.

The timing of the maximum UHI is also consistent with the expected results that the strongest UHI occur at night [10] [22] [47]. A histogram of the timing of the maximum UHI during each three day window (Figure 7) suggests that the most common time for a strong UHI is at night, more specifically in the evening between the hours of 19:00 and 00:00 local time (45.5 percent). The distribution of hours is further evidence, however, of the importance of an hourly evaluation of the UHI to capture the full magnitude of the phenomenon due to the complex dynamics over the diurnal cycle which result in time shifting of the maximum [22] [53] (Figure 8).

\section{Implications and Discussion}

This study and three method analysis finds evidence of a clear UHI signal at the regional scale in the DurhamOrange-Wake county study region resulting from land use and land cover planning decisions. The methods disagree on the magnitude of the signal however with mean signal strength in 2015 are significant, ranging from $1.4^{\circ} \mathrm{C} \pm 0.38^{\circ} \mathrm{C}$ by the mean monthly minimum method, to $5.5^{\circ} \mathrm{C} \pm 1.2^{\circ} \mathrm{C}$ by the diurnal hourly method and $2.1^{\circ} \mathrm{C} \pm 1.3^{\circ} \mathrm{C}$ using spatial analysis of remotely sensed TIR coverage. The differences in the types and granularity of the methods and data are implicated in the variation consistent with meta-analysis of experimental UHI studies in Asia and Australia (Santa 2015-Asia).

For instance, the mean monthly method controls for ideal conditions in an average sense but does not exclude data that might include less than ideal conditions including days with precipitation. The method also does not temporally align temperature signatures in the diurnal cycle of highs and lows at the stations being compared, so lag effects in the long-wave radiation emission rates near the stations are also not aligned. These short comings may be part of the reason why previous research efforts failed to capture a UHI signature that was changing over time in the study area [33]. The method does, however, have the advantage of providing the longest temporal record of observations in the study region making it a necessary and valid data point for inclusion in the present study.
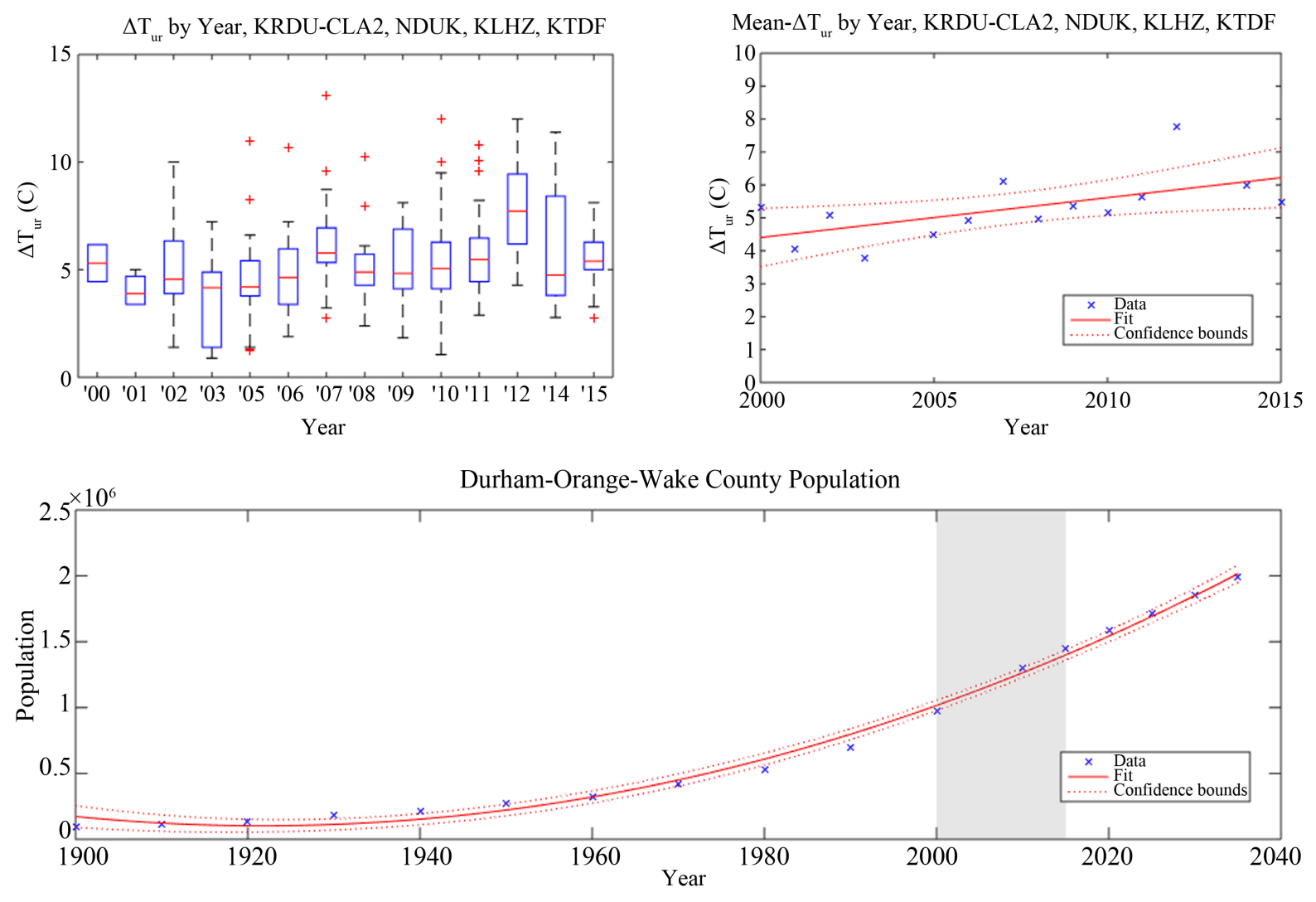

Figure 7. Diurnal hourly UHI, 2000-2015. 


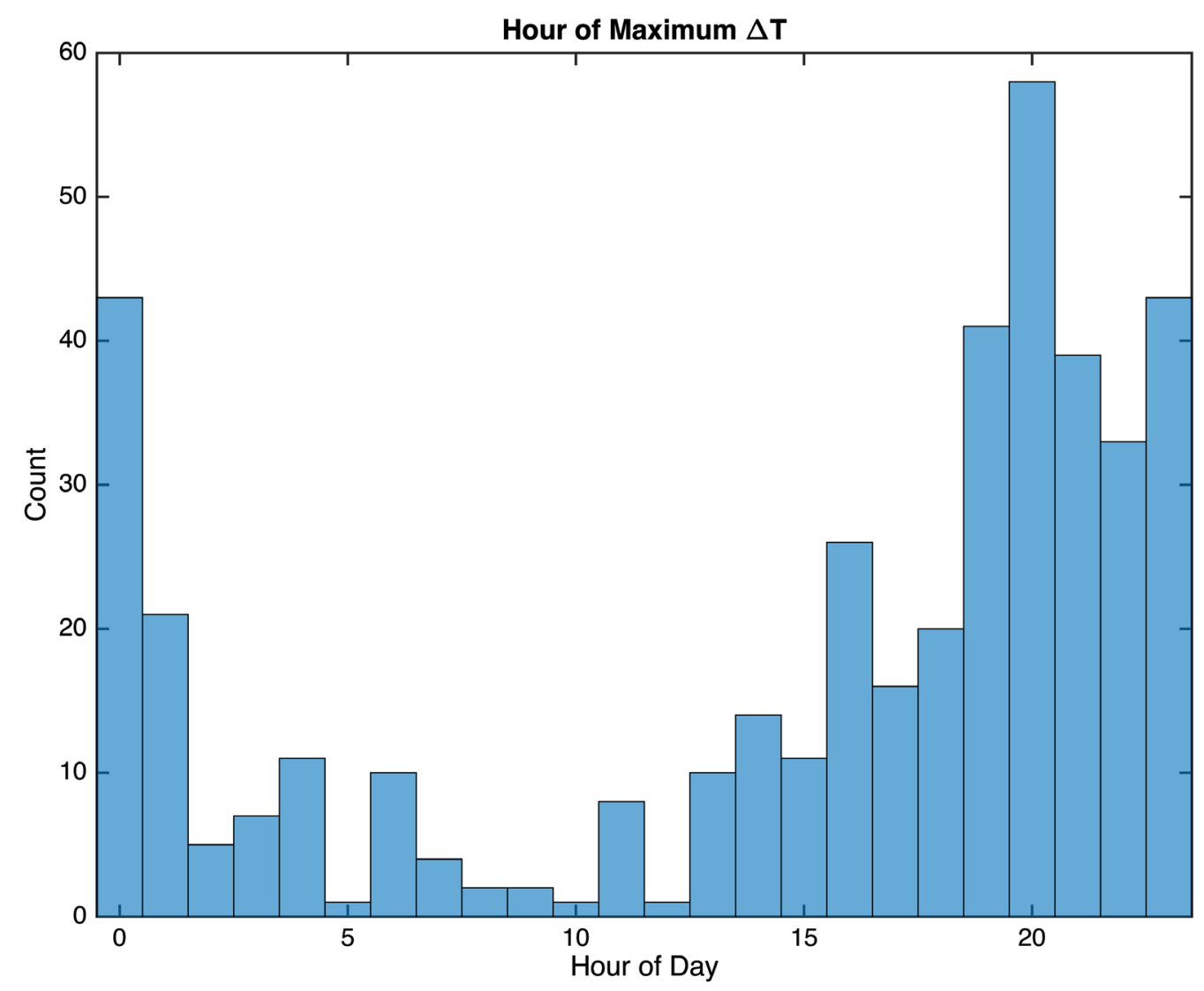

Figure 8 . Hour of maximum UHI for between 2000 -2015 by diurnal hourly method.

The mean spatial method was slightly higher than the mean temporal method, but actually in fairly good agreement considering the size of the standard deviation and variation in both methods. This should give confidence in the findings at the regional scale of the magnitude of the UHI as characterized by the present study. Additional images from the historical Landsat archive could be used in future work to verify this conclusion.

The diurnal method is by far the most granular temporal method used to characterize the magnitude of the canopy layer UHI and enables researchers to passively control for ideal UHI conditions necessary to capture the full magnitude of the UHI in the study region. Near ideal conditions over the 15-year time span of analysis were controlled by isolating maximum regional temperatures over 3-day periods with no precipitation. Over that time period, the mean regional scale UHI signal exhibits an increasing trend with nearly two degrees of change over the time span. Even under these conditions however, there was variation in the distribution of the observed UHI strength and the time of the maximum temperature delta, further evidence of the need for granularity and large data sets in assessing the magnitude of the UHI signal. This is particularly true as attention is given to smaller scales of analysis and application. At the same time, the temporal trend, while shorter than the mean monthly method, was also more clearly correlated with population increases in the study area over the time span investigated.

Despite the clear advantages of using weather station and in situ data for characterization and assessment of the UHI, remote sensing continues to be a popular tool for researchers seeking to cover larger land areas and a larger number of cities (e.g. [11] [54]). Using a single satellite image captured at the height of the afternoon heat on a clear day in late June, we find that the land surface temperature in the study area exhibits the largest temperature delta between rural and urban areas. Further, we find that the air and skin temperatures in the study area are comparable [55].

Despite a nearly net neutral land change profile in the study region since the turn of the millennium, the UHI continues to grow along with the study area population. Some recent evidence suggests that the configuration of cities, not just the overall size, is an equally important factor in the observed UHI, particularly of smaller cities 
[56]. This may be the case here, however additional work is necessary to prove this is the case. Future development in the study region, however, is likely to exacerbate this growth in the UHI regardless unless adequate steps are taken to mitigate the creation and impact of the UHI on residents and the local environment. With significant growth and densification projected in the near future, a more granular understanding of the spatial distribution and drivers is warranted to inform and enable smart growth in the region. Remote sensing promises to be this tool, however, the findings of this study indicate that a mixed method of analysis is warranted.

\section{Conclusions}

To effectively incorporate land use and land cover decisions and their environmental implications as manifested in the development of the UHI, regional and local scale knowledge is required. This research contributes to that knowledge base by undertaking a regional scale study of the UHI using remote sensing and historical weather station data from the region and its surrounding environs. The findings indicate that a UHI of $5.3^{\circ} \mathrm{C} \pm 0.97^{\circ} \mathrm{C}$ is present in the study area and that over the past 60 plus years and in particular in the last 15 years, the strength of the urban climate signal has continued to grow.

This study also confirms the findings of previous research, specifically that the UHI is the strongest at night, during clear, calm and dry conditions; and that it is a phenomenon sensitive to the size and scale of the urban environment, in this case as measured by the regional population and land cover.

As the study area continues to see rapid economic development and the planning for major infrastructure projects that will support continued growth, the importance of urban climatological conditions becomes important to ensure fair and equitable attention is paid to ensure a healthy and comfortable environment for all residents. As a first step, this study begins to address this need; however additional attention to the local scale characterization of the UHI and its correlation with different land covers would provide better granularity and more actionable information for site-specific conditions and design.

\section{References}

[1] IPCC (2013) Climate Change 2013: The Physical Science Basis. Contribution of Working Group I to the Fifth Assessment Report of the Intergovernmental Panel on Climate Change. In: Stocker, T.F., et al., Eds., Cambridge University Press, Cambridge, 1535.

[2] IPCC (2014) Climate Change 2014: Impacts, Adaptation, and Vulnerability. Part A: Global and Sectoral Aspects. Contribution of Workig Group II to the Fifth Assessment Report of the Intergovernmental Panel on Climate Change. In: Field, C.B., et al., Eds., Cambridge, United Kingdom, 1132.

[3] United Nations, D.o.E.a.S.A. (2014) Population Division, World Urbanization Prospects: The 2014 Revision, Highlights.

[4] Seto, K.C. and Shepherd, J.M. (2009) Global Urban Land-Use Trends and Climate Impacts. Current Opinion in Environmental Sustainability, 1, 89-95. http://dx.doi.org/10.1016/j.cosust.2009.07.012

[5] Parker, D.E. (2010) Urban Heat Island Effects on Estimates of Observed Climate Change. WIREs Climate Change, 1, 123-133. http://dx.doi.org/10.1002/wcc.21

[6] Potchter, O. and Ben-Shalom, H.I. (2013) Urban Warming and Global Warming: Combined Effect on Thermal Discomfort in the Desert City of Beer Sheva, Isreal. Journal of Arid Environments, 98, 113-122. http://dx.doi.org/10.1016/j.jaridenv.2013.08.006

[7] Golden, J.S., et al. (2006) Energy and Water Sustainability: The Role of Urban Climate Change from Metropolitan Infrastructure. Journal of Green Building, 1, 124-138. http://dx.doi.org/10.3992/jgb.1.3.124

[8] Lai, L.W. and Cheng, W.L. (2010) Urban Heat Island and Air Pollution-An Emerging Role for Hospital Respiratory Admissions in Urban Areas. Journal of Environmental Health, 72, 32-35.

[9] Howard, L. (1833) The Climate of London Deduced from Meteorological Observations Made in the Metropolis and at Various Places around It [Electronic Resource]. 2nd Edition, Harvey and Darton, London.

[10] Oke, T.R. (1982) The Energetic Basis of the Urban Heat Island. Quarterly Journal of the Royal Meteorological Society, 108, 1-24. http://dx.doi.org/10.1002/qj.49710845502

[11] Phelan, P.E., et al. (2015) Urban Heat Island: Mechanisms, Implications, and Possible Remedies. Annual Review of Environment and Resources, 40, 7.1-7.23. http://dx.doi.org/10.1146/annurev-environ-102014-021155

[12] Golden, J.S. and Kaloush, K.E. (2006) Mesoscale and Microscale Evaluation of Surface Pavement Impacts on the Urban Heat Island Effects. International Journal of Pavement Engineering, 7, 37-52. 
http://dx.doi.org/10.1080/10298430500505325

[13] Golden, J.S., Chuang, W.C. and Stefanov, W.L. (2009) Enhanced Classifications of Engineered Paved Surfaces for Urban Systems Modeling. Earth Interactions, 13, 1-19. http://dx.doi.org/10.1175/2009EI274.1

[14] Coseo, P. and Larsen, L. (2014) How Factors of Land Use/Land Cover, Building Configuration, and Adjacent Heat Sources and Sinks Explain Urban Heat Islands in Chicago. Landscape and Urban Planning, 125, 117-129. http://dx.doi.org/10.1016/j.landurbplan.2014.02.019

[15] Chow, W.T.L., Brennan, D. and Brazel, A. (2012) Urban Heat Island Research in Phoenix, Arizona. BAMS, 2012, 517530. http://dx.doi.org/10.1175/BAMS-D-11-00011.1

[16] Hu, L., Brunsell, N.A., Monaghan, A.J., Barlage, M. and Wilhelmi, O.V. (2014) How Can We Use MODIS Land Surface Temperature to Validate Long-Term Urban Model Simulations? Journal of Geophysical Research: Atmospheres, 119, 3185-3201. http://dx.doi.org/10.1002/2013JD021101

[17] Streutker, D.R. (2002) A Remote Sensing Study of the Urban Heat Island of Houston, Texas. International Journal of Remote Sensing, 23, 2595-2608. http://dx.doi.org/10.1080/01431160110115023

[18] Dixon, G. and Mote, T. (2003) Patterns and Causes of Atlanta's Urban Heat Island-Initiated Precipitation. Journal of Applied Meteorology and Climatology, 42, 1273-1284. http://dx.doi.org/10.1175/1520-0450(2003)042<1273:PACOAU>2.0.CO;2

[19] US Census Bureau (2016) Annual Estimates of the Resident Population for Incorporated Places of 50,000 or More. Ranked by 1 July 2014 Population, American Fact Finder. http://factfinder.census.gov/faces/tableservices/jsf/pages/productview.xhtml?src=bkmk

[20] Childs, P.P. and Raman, S. (2005) Observations and Numerical Simulations of Urban Heat Island and Sea Breeze Circulations over New York City. Pure and Applied Geophysics, 162, 1955-1980. http://dx.doi.org/10.1007/s00024-005-2700-0

[21] Uejio, C.K., Wilhelmib, O.V., Goldenc, J.S., Millsd, D.M., Gulinoe, S.P. and Samenowf, J.P. (2011) Intra-Urban Societal Vulnerability to Extreme Heat: The Role of Heat Exposure and the Built Environment, Socioeconomics, and Neighborhood Stability. Health \& Place, 17, 498-507. http://dx.doi.org/10.1016/j.healthplace.2010.12.005

[22] Santamouris, M. (2015) Regulating the Damaged Thermostat of Cities-Status, Impacts and Mitigation Challenges. Energy and Buildings, 91, 43-56. http://dx.doi.org/10.1016/j.enbuild.2015.01.027

[23] Chuang, W.-C., Goberb, P., Chowd, W.T.L. and Goldene, J. (2013) Sensitivity to Heat: A Comparative Study of Phoenix, Arizona and Chicago, Illinois (2003-2006). Urban Climate, 5, 1-18. http://dx.doi.org/10.1016/j.uclim.2013.07.003

[24] Wong, K.V., Paddon, A. and Jimenez, A. (2013) Review of World Urban Heat Islands: Many Linked to Increased Mortality. Journal of Energy Resources Technology, 135, 022101-1-022101-11. http://dx.doi.org/10.1115/1.4023176

[25] Commerce GDCO (2015) Economic Profile. http://durhamchamber.org/economic-development/economic-profile

[26] Hagler, Y. (2009) Defining US Megaregions. America 2050, Regional Planning Association, 8.

[27] Carlyle, E. (2014) America’s 20 Fastest-Growing Cities. Forbes 2014. http://www.forbes.com/sites/erincarlyle/2014/02/14/americas-20-fastest-growing-cities/

[28] Bierwagen, B.G., et al. (2009) Land-Use Scenarios: National-Scale Housing-Density Scenarios Consistant with Climate Change Storylines. USEPA, EPA, Global Change Research Program, Editor 2009, National Center for Environmental Assessment, Washington DC.

[29] Nakicenovic, N., et al. (2000) Special Report on Emissions Scenarios. IPOCC (IPCC), Editor 2000, Cambridge University Press, Cambridge.

[30] Henry, A. and Lukasina, C. (2013) 2040 Metropolitan Transportation Plan. Capital Area Metropolitan Planning Organization Durham-Chapel Hill-Carrboro Metropolitan Planning Organization.

[31] OSBM (2015) County/State Population Projections. http://www.osbm.nc.gov/demog/county-projections

[32] Belda, M., Holtanová, E., Halenka, T. and Kalvová, J. (2014) Climate Classification Revisited: From Koppen to Trewartha. Climate Research, 59, 1-13. http://dx.doi.org/10.3354/cr01204

[33] Chen, F. and Konrad, C.E. (2006) A Synoptic Climatology of Summertime Heat and Humidity in the Piedmont Region of North Carolina. Journal of Applied Meteorology and Climatology, 45, 674-685. http://dx.doi.org/10.1175/JAM2345.1

[34] Fuhrmann, C.M., Konrada, C.E., Kovacha, M.M. and Perkinsa, D.J. (2011) The August 2007 Heat Wave in North Carolina: Meteorological Factors and Local Variability. Physical Geography, 32, 217-240.

[35] King, V.J. and Davis, C. (2007) A Case Study of Urban Heat Islands in the Carolinas. Environmental Hazards, 7, 353-359. http://dx.doi.org/10.1016/j.envhaz.2007.09.005 
[36] Zhao, L., Lee, X.H., Smith, R.B. and Oleson, K. (2014) Strong Contributions of Local Background Climate to Urban Heat Islands. Nature, 511, 216-219. http://dx.doi.org/10.1038/nature13462

[37] Bowler, D.E., Buyung-Ali, L., Knight, T.M. and Pullin, A.S. (2010) Urban Greening to Cool Towns and Cities: A Systematic Review of the Empirical Evidence. Landscape and Urban Planning, 97, 147-155. http://dx.doi.org/10.1016/j.landurbplan.2010.05.006

[38] Bigsby, K.M., McHale, M. and Hess, G.R. (2014) Urban Morphology Drives the Homogenization of Tree Cover in Baltimore, MD, and Raleigh, NC. Ecosystems, 17, 212-227. http://dx.doi.org/10.1007/s10021-013-9718-4

[39] Schwarz, K., et al. (2015) Trees Grow on Money: Urban Tree Canopy Cover and Environmental Justice. PLoS ONE, 10, e0122051 http://dx.doi.org/10.1371/journal.pone.0122051

[40] Meineke, E.K., Dunn, R.R., Sexton, J.O. and Frank, S.D. (2013) Urban Warming Drives Insect Pest Abundance on Street Trees. PLoS ONE, 8, e59687. http://dx.doi.org/10.1371/journal.pone.0059687

[41] Lippmann, S.J., Fuhrmannb, C.M., Wallerd, A.E. and Richardsona, D.B. (2013) Ambient Temperature and Emergency Department Visits for Heat-Related Illness in North Carolina, 2007-2008. Environmental Research, 124, 35-42. http://dx.doi.org/10.1016/j.envres.2013.03.009

[42] Barsi, J.A., et al. (2005) Earth Observing Systems X. In SPIE, Bellingham, WA.

[43] USG Survey (2015) Using the USGS Landsat 8 Product. http://landsat.usgs.gov/Landsat8 Using Product.php

[44] Homer, C.G., et al. (2015) Completion of the 2011 National Land Cover Database for the Conterminous United StatesRepresenting a Decade of Land Cover Change Information. Photogrammetric Engineering and Remote Sensing, 81, 345-354.

[45] Anderson, J.R., Hardy, E.E., Roach, J.T. and Witmer, R.E. (1976) A Land Use And Land Cover Classification System For Use With Remote Sensor Data. United States Department of the Interior, Geological Survey, Washington DC.

[46] Golden, J.S. (2004) The Build Environment Induced Urban Heat Island Effect in Rapidly Urbanizing Arid Regions-A Sustainable Urban Engineering Complexity. Environmental Sciences, 1, 321-349. http://dx.doi.org/10.1080/15693430412331291698

[47] Arnfield, A.J. (2003) Two Decades of Urban Climate Research: A Review of Turbulence, Exchanges of Energy and Water, and the Urban Heat Island. International Journal of Climatology, 23, 1-26. http://dx.doi.org/10.1002/joc.859

[48] Oke, T.R. (1981) Canyon Geometery and the Nocturnal Urban Heat Island: Comparison of Scale Model and Field Observations. Journal of Climatology, 1, 237-254. http://dx.doi.org/10.1002/joc.3370010304

[49] USG Survey (2015) Multi-Resolution Land Characteristics Consortium (MRLC). http://www.mrlc.gov/

[50] NCOSB Management (2015) Demographics. http://www.osbm.nc.gov/facts-figures/demographics

[51] US Census Bureau (2015) Population. http://www.census.gov/topics/population.html

[52] DC-CP Department (2015) Population Projections. DC-CP Department, Editor 2015, Durham Demographics.

[53] Santamouris, M. (2015) Analyzing the Heat Island Magnitude and Characteristics in One Hundred Asian and Australian Cities and Regions. Science of the Total Environment, 512-513, 582-598. http://dx.doi.org/10.1016/j.scitotenv.2015.01.060

[54] Clinton, N. and Gong, P. (2013) MODIS Detected Surface Urban Heat Islands and Sinks: Global Locations and Controls. Remote Sensing of Environment, 134, 294-304. http://dx.doi.org/10.1016/j.rse.2013.03.008

[55] Voogt, J. and Oke, T.R. (2003) Thermal Remote Sensing of Urban Climates. Remote Sensing of Environment, 86, 370384. http://dx.doi.org/10.1016/S0034-4257(03)00079-8

[56] Debbage, N. and Shepherd, J.M. (2015) The Urban Heat Island Effect and City Contiguity. Computers, Environment and Urban Systems, 54, 181-194. http://dx.doi.org/10.1016/j.compenvurbsys.2015.08.002 


\section{Submit or recommend next manuscript to SCIRP and we will provide best service for you:}

Accepting pre-submission inquiries through Email, Facebook, Linkedin, Twitter, etc A wide selection of journals (inclusive of 9 subjects, more than 200 journals)

Providing a 24-hour high-quality service

User-friendly online submission system

Fair and swift peer-review system

Efficient typesetting and proofreading procedure

Display of the result of downloads and visits, as well as the number of cited articles

Maximum dissemination of your research work

Submit your manuscript at: http://papersubmission.scirp.org/ 